DOI

\title{
БІОХІМІЧНІ ТА ФІЗІОЛОГІЧНІ ЗМІНИ В КРОВІ ПРИ ЕКСПЕРИМЕНТАЛЬНІЙ ЕМФІЗЕМІ
}

\author{
๑Я. І. Русінчук, В. І. Коржов, І. В. Ліскіна, О. О. Мельник \\ Державна установа «Національний інститут фтизіатрії і пульмонології \\ імені Ф. Г. Яновського НАМН України»
}

РЕЗЮМЕ. У роботі показано, що під час розвитку експериментальної емфіземи в мембрані еритроцитів тварин спостерігаються суттєві біохімічні та структурні зміни.

КЛЮчОВІ СЛОВА: емфізема, мембрана еритроцитів, оксидантна та антиоксидантна системи.

Вступ. За останнє десятиліття стало загальновизнаним, що хронічні обструктивні захворювання легень (ХОЗЛ), i, як наслідок, легенева емфізема, мають значне поширення у всьому світі та істотно впливають на якість і тривалість життя громадян у різних країнах. Статистика свідчить, що близько 90 \% всіх пацієнтів з хронічними обструктивними захворюваннями легень $\epsilon$ курцями. Сигаретний дим $\epsilon$ багатим джерелом оксидантів. Окиснювальний стрес збільшує генерацію оксидантів, які не можуть бути нейтралізовані антиоксидантними захисними механізмами організму. Ліпіди і протеїни, що входять до складу різноманітних структур клітини, $\epsilon$ дуже чутливими до окиснювального пошкодження. Кисневі радикали можуть модифікувати бічні ланцюги амінокислот, змінювати форму білків, порушувати пептидні зв'язки, і робити білки більш сприйнятливими до протеолітичної деградації [1].

Кров дуже чутливо реагує на досить незначні фізіологічні і, тим більше, патологічні зміни в організмі [2]. Еритроцити, в силу особливостей свого функціонування, мають низьку здатність справлятися з окиснювальним стресом, що може призводити до значних змін у самому еритроциті [3]. Цитоархітектоніка та біохімічний склад еритроцитів віддзеркалюють не лише стан клітинних мембран самих еритроцитів, але й організму в цілому. Ось чому зміни мембран еритроцитів можуть слугувати індикатором тяжкості гіпоксії та ефективності терапії, яка при цьому проводиться [4]. 3 огляду на це, вивчення структурних та біохімічних змін в еритроциті при розвитку експериментальної емфіземи може мати важливе значення як для поглиблення і розширення теоретичних знань, так і для практичного застосування в клініці.

Матеріал і методи дослідження. Досліди проведено на білих безпородних щурах вагою 180-200 г. Під легким наркозом із застосуванням медичного ефіру щурам вводили в трахею розчин папаїну (Sigma, США) - ферменту, який належить до цистеїнових протеаз та здатен каталізувати гідроліз білків і пептидів, спричиняючи таким чином руйнування легеневої тканини. Ступінь та характер ушкодження легень визначали при гіс- тологічному дослідженні. Евтаназію тварин після завершення експерименту проводили відповідно до «Європейської конвенціії про захист хребетних тварин, що використовуються для дослідних та інших наукових цілей» [5] шляхом декапітації під ефірним наркозом.

Вміст церулоплазміну в плазмі крові визначали за модифікованим методом Ревіна [6]. Вміст ОШ визначали за методикою Хишиктуєва і співавт. $[7,8]$.

Визначення осмотичної резистентності еритроцитів проводили за допомогою розробленої нами методики. У три пробірки вносили розчини наступних концентрацій: 1) 100 \% фізіологічний розчин; 2) $50 \%$ фізіологічний розчин + 50 \% дистилят; 3) $100 \%$ дистилят. Потім у кожну з пробірок додавали по 50 мкл відмитих еритроцитів і поміщали пробірки у термостат на 60 хвилин при температурі $37^{\circ} \mathrm{C}$. Після цього пробірки з розчинами центрифугували 10 хвилин на швидкості 3000 обертів за хвилину. Потім вносили у кожну пробірку по 150 мкл насиченого розчину гексаціаноферату (III) калію або «червоної кров'яної солі» (K3[Fe(CN)6]) та визначали оптичну густину на довжині хвилі 630 нм. Результат, отриманий у дистиляті, приймали за 100 \% руйнування еритроцитів.

Перевірку розподілу отриманих даних на нормальність проводили W тестом Шапіро - Вілка. Порівняння вибірок проводили з використанням t-критерію Стьюдента за допомогою комп'ютерної програми Statistica 6.0.

Результати й обговорення. Досліди проведено на двох групах щурів: 1 група отримувала папаїн в дозі 50 мг/кг ваги, а друга - в дозі 100 мг/кг ваги. Строк спостереження складав 2 тижні в обох групах.

У тварин першої групи розвивалася емфізема переважно центролобулярного типу, при якій зміни відбуваються в першу чергу в центральній частині ацинуса, що відповідає респіраторним бронхіолам, які розширюються, оскільки їхні стінки розтягуються та зрідка можуть спостерігатися їх надриви. Респіраторні бронхіоли оточені незміненими або мало зміненими альвеолами, розташованими на периферії ацинуса. Подібний тип 
Огляди літератури, оригінальні дослідження, погляд на проблему

емфіземи легень у клінічній практиці частіше спостерігається у хворих на хронічний обструктивний бронхіт і визначається переважно у верхніх ділянках легень (у задніх та апікальних сегментах), інколи у верхівкових сегментах нижніх часток.

За рівнем виразності гістологічних змін легеневої тканини у першій групі щурів спостерігали I ступінь емфіземи (слабко виражена). Було помітне незначне розширення входу альвеол, зменшення їхньої глибини та збільшення площі провідної частини респіраторних бронхіол. Вираженого зменшення кількості клітин у стінках альвеол не спостерігали. Відмічали дещо звужені капіляри. Крім того, була зменшена резервна звивистість альвеолярних клітин. Істинні розриви альвеолярних перегородок практично не спостерігалися.

У другій групі тварин розвивалася переважно панлобулярна (панацинарна) емфізема, яка характеризувалася відносно рівномірним ураженням ацинусів, при цьому процес охоплював весь ацинус, без вибіркових змін у ділянці респіраторних бронхіол або альвеол. У клініці така форма частіше спостерігається при первинній дифузній емфіземі, у хворих з гомозиготним дефіцитом альфа-1-антитрипсину - білка, що утворюється в печінці, основною функцією якого $\epsilon$ захист легеневої тканини від її руйнування еластазою [9].

Зміни у легеневій тканині щурів у другій групі були значно виразнішими, ніж у першій, і найбільшою мірою відповідали II ступеню емфізематозних змін. Була збільшена, порівняно з першою групою, ширина входу в альвеоли. Зустрічалися значно розширені альвеолярні респіраторні ходи і респіраторні бронхіоли. Спостерігали помітне зменшення кількості клітин в альвеолярних стінках. Окрім того, визначали незначні ділянки плазморагій в альвеоли, що, ймовірно, було наслідком пошкодження стінок капілярів, які розташовані в міжальвеолярних перетинках.

На фоні морфологічних змін у легенях при експериментальній емфіземі спостерігали значне зростання осмотичної резистентності еритроцитів: якщо в контролі в 50 \% фізіологічному розчині за годину інкубації руйнувалося $63 \%$ еритроцитів, то після введення щурам папаїну в дозі 100 мг/кг ваги на 2 тиждень за тих же умов експерименту руйнувався лише $21 \%$ еритроцитів. Слід зазначити, що на 3 тиждень досліджень спостерігалася певна тенденція до повернення осмотичної резистентності до норми: руйнування еритроцитів складало вже $31 \%$.

Визначення осмотичної резистентності еритроцитів (ОРЕ) є одним з найдоступніших у лабораторній діагностиці методів оцінки фізико-хімічних властивостей мембран еритроцитів. Зміни ОРЕ спостерігаються при низці захворювань, оскільки при гемолітичних анеміях (спадкова мікросфероцитарна, автоімунна) значення цього показника знижується, а при таласемії, гемоглобінопатіях, механічній жовтяниці, навпаки, підвищується [10].

У роботі Арифханової та співавт. [11] було показано, що при експериментальній папаїновій емфіземі спостерігається переважна тенденція до розвитку макроцитозу еритроцитів, що свідчить про насичення мембрани еритроцитів холестерином. Відсутній ефект при інкубації еритроцитів 3 адренергічним агоністом при збереженні холінергічної реактивності зазвичай свідчить про значні молекулярно-структурні зміни ліпіднобілкового та глікопротеїдного складу мембран еритроцитів.

На другий тиждень після введення щурам папаїну в дозі 100 мг/кг ваги спостерігалася тенденція до зростання концентрації церулоплазміну в плазмі крові - на 5,4 \% (від 2,98 ммоль/л в контролі до 3,14 ммоль/л). Через три тижні зростання концентрації церулоплазміну в плазмі становило вже 37,6 \% (до 4,10 ммоль/л).

Церулоплазмін - мідьвмісний альфа-2-глобулін плазми крові. Крім функції транспорту міді до тканин, церулоплазмін $\epsilon$ каталізатором при окисненні заліза (якщо церулоплазмін відсутній залізо накопичується в тканинах), бере участь в окисленні катехоламінів і серотоніну, має антиоксидантну (запобігає окисненню ліпідів клітинних мембран) та протизапальну (пригнічує гістаміназу сироватки) дію. Низькі концентрації церулоплазміну реєструються при хворобі Вільсона (гепатолентикулярна дегенерація), а їх підвищення - при гострих або запальних процесах, оскільки церулоплазмін $\epsilon$ реагентом гострої фази.

Відомо, що практично при будь-якій патології і стресових впливах на організм активуються процеси вільнорадикального окиснення. У якості пошкоджувальних агентів виступають активні форми кисню, які $є$ високоефективним інструментом локального впливу за рахунок високої реакційної здатності. При значному напруженні захисних систем клітин кількість активних форм кисню зростає настільки, що виникає окиснювальний стрес з деструктивними змінами мембранних структур. Активні форми кисню індукують процеси перекисного окиснення ліпідів (ПОЛ) у біологічних мембранах. Кінцеві молекулярні продукти ПОЛ в результаті реакцій взаємодії вторинних продуктів з фізіологічно важливими амінами (амінокислотами, білками і білковими компонентами фосфоліпідів, нуклеотидами, гормонами та вітамінами) утворюють полімерні сполуки - основи Шифа (ОШ) [2].

При застосуванні папаїну (50 мг/кг ваги) відмічали зростання вмісту основ Шифа в гептано- 
Огляди літератури, оригінальні дослідження, погляд на проблему

вій фракції: на 42 \% (через два тижні з моменту введення щурам папаїну) і на $122 \%$ - наприкінці третього тижня від початку експерименту, що свідчило про активацію процесів ПОЛ у фракції нейтральних ліпідів. Нейтральні ліпіди (зокрема, тригліцериди і складні ефіри холестерину) не входять у значних кількостях до складу біологічних мембран, проте вони є важливими компонентами ліпопротеїнових комплексів. Водночас концентрація основ Шифа в ізопропаноловій фракції залишалася незмінною, що свідчило про відсутність значної активності пол у фосфоліпідах мембрани еритроцитів (принаймні, на другому і третьому тижнях розвитку експериментальної емфіземи).

Ми можемо зробити висновок, що хоча на фоні розвитку емфіземи і активуються процеси
ПОЛ (насамперед у фракції нейтральних ліпідів), однак водночас відбувається активація системи антиоксидантного захисту організму (про що свідчить зростання концентрації церулоплазміну в плазмі крові).

Висновок. Викликана папаїном експериментальна емфізема у щурів призводить до значної активізації процесів перекисного окиснення ліпідів, що супроводжується значними структурними перебудовами в мембрані еритроцитів, які помітні за змінами фізичних властивостей еритроцитів, а саме - значно зростає їх резистентність до перебування у гіпотонічному розчині. При цьому в організмі активується захисна антиоксидантна система, яка дозволяє, до певної міри, запобігти негативному впливу активних форм кисню на ліпідний шар еритроцитів.

\section{ЛITEPATУPA}

1. The role of oxidative stress in the pathogenesis of pulmonary emphysema / D. Vucević, T. Radosavljević, S. Zunić [et al.] // Med. Pregl. - 2005. - Vol. 58. - P. 472-477.

2. Клиническая лабораторная диагностика: методы исследования / И. А. Зупанец, С. В. Мисюрева, В. В. Прописнова [и др.] ; под ред. И. А. Зупанца. -Харьков : Изд-во НФаУ «Золотые страницы», 2005. - 200 с.

3. Edwards C. J. Oxidative Stress in Erythrocytes / C. J. Edwards, J. Fuller // Comp Haematol Int. - 1996. Vol. 6. - P. 24-31.

4. Мембранопротекторное действие перфторана на эритроциты при острой кровопотере / В. В. Мороз, А. К. Кирсанова, И. С. Новодержкина [и др.] // Общая реаниматология. - 2011. - № 1. - С. 5-10.

5. European Convention for the Protection of Vertebrate Animals used for Experimental and Other Scientific Purposes // European Treaty Series. - 1986. - № 123.

6. Использование биохимических методов исследования для диагностики и контроля за лечением больных хроническими воспалительными заболеваниями : методические рекомендации / [В. И. Малюк, А. В. Максимова, О. К. Комиссар]. - К. : Киевский НИи фтизиатрии и пульмонологии, 1986. - 19 с.
7. Методы изучения стрессовых и адаптационных реакций организма по показателям системы крови / [А. В. Дерюгина, А. С. Корягин, С. В. Копылова, М. Н. Таламанова]. - Нижний Новгород : Издательство Нижегородского госуниверситета, 2010. - 25 с.

8. Хышиктуев Б. С. Методы определения продуктов перекисного окисления липидов в конденсате выдыхаемого воздуха и их клиническое значение / Б. С. Хышиктуев, Н. А. Хышиктуева, В. Н. Иванов // Клиническая лабораторная диагностика. - 1996. - № 3. C. 13-15.

9. Mahadeva R. Alpha1-antitrypsin deficiency, cirrhosis and emphysema / R. Mahadeva, D. Lomas // Thorax. - 1998. - Vol. 53. - P. 501-505.

10. Патологическая физиология / А. Д. Адо, Л. М. Ишимова, И. П. Гаранина [и др.] ; под. ред. А. Д. Адо, Л. М. Ишимовой. - М. : Медицина, 1980. - 520 с.

11. Модификация мембран эритроцитов перфтораном при папаиновой эмфиземе у крыс / С. И. Арифханова, Н. И. Зоирова, Х. У. Рахматуллаев, Ю. Х. Таджиходжаева // Патологическая физиология и экспериментальная терапия. - 2006. - № 1. - С. 18-19.

\title{
BIOCHEMICAL AND PHYSIOLOGICAL CHANGES IN THE BLOOD IN EXPERIMENTAL EMPHYSEMA
}

\author{
@la. I. Rusinchuk, V. I. Korzhov, I. V. Liskina, O. A. Melnyk \\ F. Yanovskyi National Institute of Phthisiology and Pulmonology
}

SUMMARY. It was shown that during the development of experimental emphysema there are significant biochemical and structural changes in the membrane of red blood cells of rats.

KEY WORDS: emphysema, membrane of red blood cells, oxidant and antioxidant systems. 